\title{
Human Resource Development of Birbhum District - A Critical Study
}

\author{
${ }^{1}$ Debasish Roy, ${ }^{2}$ Anushri Mondal \\ M.Phil Scholar in Rabindra Bharati University, CSIR NET in Earth, Atmospheric, Ocean and Planetary \\ Science. UGC NET in Geography, Rajiv Gandhi National Junior Research Fellow and Asst. Teacher Ahiran \\ Hemangini Vidyayatan High school., M.A, NET
}

\begin{abstract}
In this paper we discuss the human resource development of Birbhum District. The data have been collected from District Statistical Handbook, District census report of 2001 and District Human Development Report 2009.A large part of the Birbhum District is still backward with respect to human resource development. Aim of this paper is to study the cause of the backwardness of this district. "HRD is the process of determining the optimum methods of developing and improving the human resources of an organization and the systematic improvement of the performance of employees through training, education and development and leadership for the mutual attainment of organizational and personal goals" (Smith). HRD is an important topic of present time. It is considered by management professionals, as sub discipline of Human Resource Management( HRM), but many researchers have, broadened the scope and integrated the concept of HRD by looking it from socioeconomic angle and giving it other dimension such as physical, intellectual, psychological, social, political, moral and spiritual development.
\end{abstract}

\section{Introduction:}

Human Resource Development is the ultimate goal of National Development. HRD is the process of increasing the knowledge, the skills, and the capacities of all the people in a society. In economic and terms, it could be described as the accumulation of human capital and its effective investment in the development of an economy. In political terms, human resource development prepares people for adult participation in political processes, particularly as citizens in a democracy. From the social and cultural points of view, the development of human resources helps people to lead fuller and richer lives, less bound by tradition. In short, the processes of human resource development unlock the door to modernisation. Human Resource Development (HRD) is an important and very attention receiving discipline of present time. It is a relatively young academic discipline but an old and well-established field of practice (Swanson and Holton, n.d). Researchers have developed new theories and conceptual frameworks that address a broad range of phenomena of interest to the HRD profession (Torraco 2004). A key area of inquiry has been to try and figure out the current boundaries of HRD (Metcalfe and Rees, 2005) but defining HRD has not been so straightforward, and the writers and researchers are continuously debating the issue, and there seems to be no consensus, despite of the fact that numerous efforts have been made to define HRD (Haslinda 2009). According to Rao (1995) the scope of HRD is extended, at one side, to developing competencies of human resource by enhancing knowledge, building skill, changing attitude and teaching values, and at other side, creation of conditions through public policy, programs and other interventions to help people to apply these competencies for their own and others' benefits and making things happen

\section{Study Area:}

Birbhum district is situated between $23^{\circ} 33^{\prime}$ and $24^{\circ} 35^{\prime}$ north latitude and between $87^{\circ} 10^{\prime}$ and $88^{\circ} 2^{\prime}$ east longitude. Birbhum is the northernmost district of the Burdwan Division. It extends over 1752 square miles, and has a population, according to the census of 2011, of 3502387 persons. The principal town, which is also the Administrative Headquarters of District, is Suri. Birbhum is bounded on the north by the Santal Parganas and the District of Murshidabad and Burdwan, on the south by Bardwan District, the Ajai river forming the boundary line for entire distance, and on the west by the Santal Parganas. The district is characterized by an undulating topography caused by the chhotanagpur plateau that passes through the western borders of the district. The land terrain slopes down towards the east and merges with the alluvial plains of the Ganga. The geological formations represented in Birbhum are Archaean gneiss, the Gondwana system, laterite, and Gangetic alluvium. The climate of the district is generally dry, mild and healthy. Sixty- nine percent. Of population are supported by agriculture, 11.7 per cent. By industries, 1.5 per cent. By the professions, and 0.4 per cent. By commerce. 


\section{LOCATION MAP OF BIRBHUM DISTRICT}

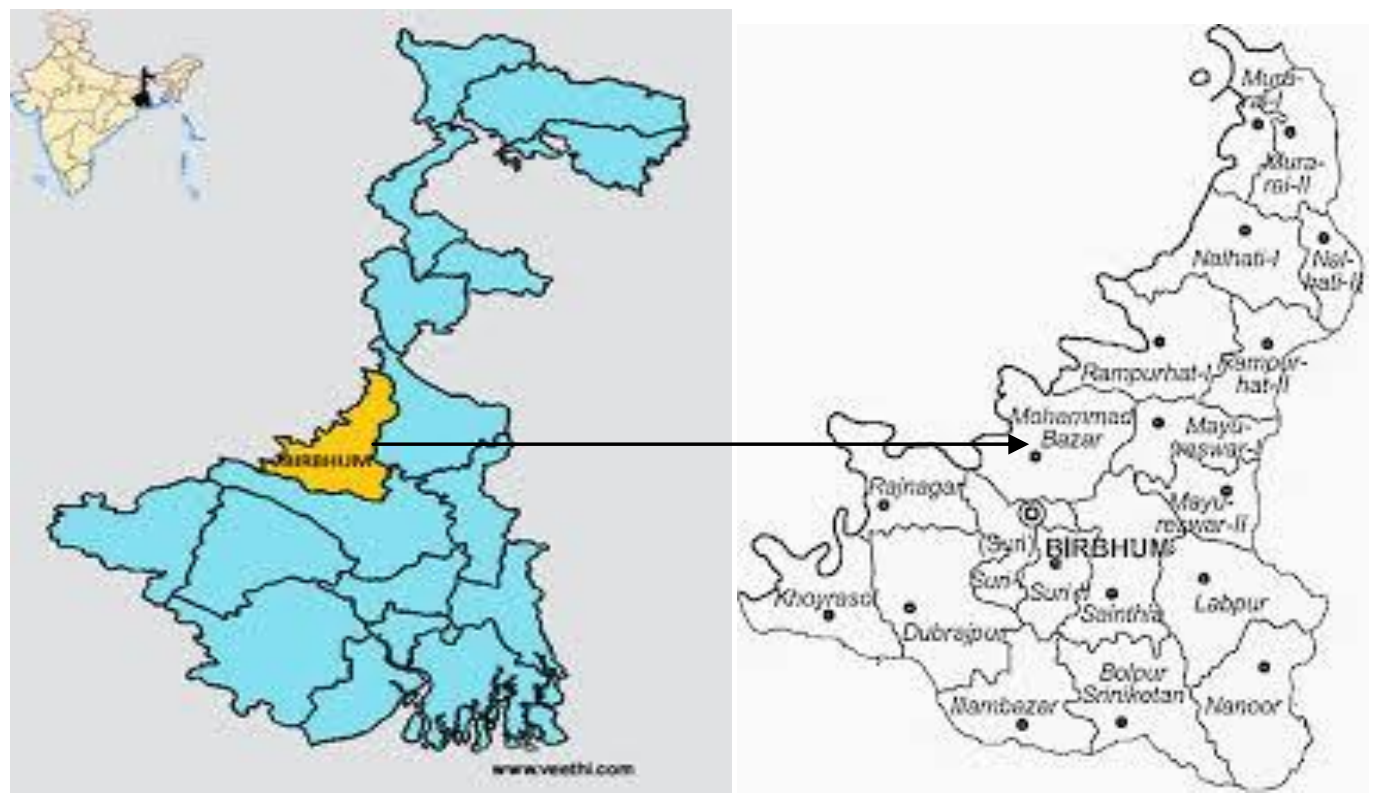

III. Methodology: -

The date required for the study have been collected from Birbhum District Statistical Handbook 20102011, Birbhum District Statistical Handbook 2001 and Birbhum District Human Development Report 2009. For identifying the level of human resource development, following indicators have been applied

1. Index of Urbanization $=($ Urban Population of the Block $\div$ Total Population of the block $) \times 100$

2. Index of Workers $=($ Total Workers of the block $\div$ Total Population of the block $) \times 100$

3. Index of Literacy $=($ Literate Population of the block $\div$ Total Population of the block $) \times 100$

4. Index of Female Literacy $=($ Female Literates of the block $\div$ Total Female Population of the block $) \times 100$

5. Index of Women Self-Help Groups $=($ No. of Women Self-Help Groups $\div$ Total No of Self-Help Groups $) \times$ 100

6. Index of Schools $=($ Total Schools of the Block $\div$ Total Students of the Block $) \times 100$

\section{Results And Discussion:-}

Index of Urbanization: Urbanisation is one of the important measures of human resource development. The urban area is high development of human resource. Communication network, Educational instutions, Infrastructure facility are good from urban area. The urbanization index is thus calculated as-

Index of Urbanization $=($ Urban Population of the Block $\div$ Total Population of the block $) \times 100$

Table 1

Index of urbanisation

\begin{tabular}{|l|l|l|l|l|}
\hline $\begin{array}{l}\text { Name of C.D } \\
\text { Blocks }\end{array}$ & Total Population & Urban Population & $\begin{array}{l}\text { Index } \\
\text { Urbanisation }\end{array}$ & of \\
\hline Nalhati-I & 208642 & 20824 & 9.981 & 6 \\
\hline Nalhati-II & 107658 & 0 & 0 & 7 \\
\hline Murarai-I & 154342 & 0 & 0 & 7 \\
\hline Murarai-II & 177748 & 0 & 0 & 7 \\
\hline Mayureswar-I & 139733 & 0 & 0 & 7 \\
\hline Mayureswar-II & 113031 & 0 & 0 & 7 \\
\hline Rampurhat-I & 159193 & 50613 & 31.793 & 3 \\
\hline Rampurhat-II & 158742 & 0 & 0 & 7 \\
\hline Mohammad Bazar & 139465 & 0 & 0 & 7 \\
\hline Sainthia & 175645 & 47556 & 27.075 & 4 \\
\hline Dubrajpur & 159011 & 32752 & 20.597 & 5 \\
\hline Rajnagar & 69692 & 0 & 0 & 7 \\
\hline Suri-I & 96476 & 61806 & 64.064 & 1 \\
\hline Suri-II & 77001 & 0 & 0 & 7 \\
\hline Khoyrasole & 135101 & 0 & 0 & 7 \\
\hline Bolpur-Sriniketan & 178111 & 65693 & 36.883 & 2 \\
\hline Labhpur & 176865 & 0 & 0 & 7 \\
\hline Nanoor & 193775 & 0 & 0 & 7 \\
\hline Illambazar & 145182 & 0 & 0 & 7 \\
\hline
\end{tabular}




\section{Source: - Computed by the authors}

Index of Workers:- Worker population indicate directly good economic base of the region. Hence high number of workers is associated with higher degree of human resource development. The formula of index is as following-

Index of Workers $=($ Total Workers of the block $\div$ Total Population of the block $) \times 100$

Table 2

Index of Workers

\begin{tabular}{|c|c|c|c|c|}
\hline Name of C.D Blocks & Total Population & Total Workers & Index of Workers & Ranks \\
\hline Nalhati -I & 208642 & 73357 & 35.159 & 14 \\
\hline Nalhati-II & 107658 & 35879 & 33.327 & 17 \\
\hline Murarai-I & 154342 & 50520 & 32.733 & 18 \\
\hline Murarai-II & 177748 & 57581 & 32.395 & 19 \\
\hline Mayureswar-I & 139733 & 53701 & 38.431 & 7 \\
\hline Mayureswar-II & 113031 & 43097 & 38.128 & 9 \\
\hline Rampurhat-I & 159193 & 70571 & 44.330 & 3 \\
\hline Rampurhat-II & 158742 & 55568 & 35.005 & 16 \\
\hline Mohammad Bazar & 139465 & 52446 & 37.605 & 10 \\
\hline Sainthia & 175645 & 67463 & 38.409 & 8 \\
\hline Dubrajpur & 159011 & 63296 & 39.806 & 6 \\
\hline Rajnagar & 69692 & 31918 & 45.799 & 2 \\
\hline Suri-I & 96476 & 41309 & 42.818 & 5 \\
\hline Suri-II & 77001 & 38045 & 49.408 & 1 \\
\hline Khoyrasole & 135101 & 47433 & 35.109 & 15 \\
\hline Bolpur-Sriniketan & 178111 & 77886 & 43.729 & 4 \\
\hline Labhpur & 176865 & 62601 & 35.395 & 13 \\
\hline Nanoor & 193775 & 71469 & 36.882 & 11 \\
\hline Illambazar & 145182 & 53029 & 36.526 & 12 \\
\hline
\end{tabular}

Source: - Computed by the authors.

Index of Literacy: - Literacy is only base which created overall development of the any regions. It is, therefore, most important index to measure the level of human resource development. The index has been calculated on the basis of the following formula-

Index of Literacy $=($ Literate Population of the block $\div$ Total Population of the block $) \times 100$

Table 3

Index of Literacy

\begin{tabular}{|l|l|l|l|l|}
\hline Name of C.D Blocks & Total Population & Literate Population & Index of Literacy & Ranks \\
\hline Nalhati -I & 208642 & 109883 & 52.666 & 6 \\
\hline Nalhati-II & 107658 & 54027 & 50.184 & 14 \\
\hline Murarai-I & 154342 & 57156 & 37.032 & 19 \\
\hline Murarai-II & 177748 & 66201 & 37.244 & 18 \\
\hline Mayureswar-I & 139733 & 77198 & 55.247 & 1 \\
\hline Mayureswar-II & 113031 & 60089 & 53.162 & 4 \\
\hline Rampurhat-I & 159193 & 82321 & 51.711 & 11 \\
\hline Rampurhat-II & 158742 & 84042 & 52.943 & 5 \\
\hline Mohammad Bazar & 139465 & 63310 & 45.395 & 17 \\
\hline Sainthia & 175645 & 96608 & 55.002 & 2 \\
\hline Dubrajpur & 159011 & 74837 & 47.064 & 16 \\
\hline Rajnagar & 69692 & 34153 & 49.006 & 15 \\
\hline Suri-I & 96476 & 50799 & 52.655 & 7 \\
\hline Suri-II & 77001 & 41052 & 53.314 & 3 \\
\hline Khoyrasole & 135101 & 69513 & 51.453 & 12 \\
\hline Bolpur-Sriniketan & 178111 & 91199 & 51.203 & 13 \\
\hline Labhpur & 176865 & 93013 & 52.590 & 8 \\
\hline Nanoor & 193775 & 100541 & 51.885 & 10 \\
\hline Illambazar & 145182 & 75847 & 52.243 & 9 \\
\hline
\end{tabular}

Source: - Computed by the authors. 
Index of Female Literacy:- In Indian situations females have been neglected for long. The sex ratio of India is bad. They are not considered on equal footing for development. Therefore attributes of females, particularly literacy of female, can be regarded as important parameter to measure the level of human resource development. The index has been calculated on the basis of the following formula-

Index of Female Literacy $=($ Female Literates of the block $\div$ Total Female Population of the block $) \times 100$

Table 4

Index of Female Literacy.

\begin{tabular}{|l|l|l|l|l|}
\hline Name of C.D Blocks & $\begin{array}{l}\text { Total } \\
\text { Population }\end{array}$ & Female & Female Literates of Female & Ranks \\
\hline Nalhati-I & 101115 & 44743 & 44.250 & 8 \\
\hline Nalhati-II & 52682 & 22499 & 42.707 & 13 \\
\hline Murarai-I & 75128 & 22392 & 29.805 & 19 \\
\hline Murarai-II & 87275 & 26424 & 30.277 & 18 \\
\hline Mayureswar-I & 68083 & 31342 & 46.035 & 2 \\
\hline Mayureswar-II & 54846 & 24117 & 43.972 & 9 \\
\hline Rampurhat-I & 77844 & 33323 & 42.807 & 10 \\
\hline Rampurhat-II & 76823 & 34049 & 44.321 & 7 \\
\hline Mohammad Bazar & 68081 & 24756 & 36.363 & 17 \\
\hline Sainthia & 85597 & 39724 & 46.408 & 1 \\
\hline Dubrajpur & 77642 & 28768 & 37.052 & 16 \\
\hline Rajnagar & 34180 & 13147 & 38.464 & 15 \\
\hline Suri-I & 46537 & 20287 & 43.593 & 12 \\
\hline Suri-II & 37411 & 16748 & 44.768 & 4 \\
\hline Khoyrasole & 65316 & 26569 & 40.678 & 14 \\
\hline Bolpur-Sriniketan & 87228 & 37462 & 42.947 & 34.618 \\
\hline Labhpur & 85800 & 38282 & 44.694 & 6 \\
\hline Nanoor & 94974 & 42448 & 43.766 & 5 \\
\hline Illambazar & 70454 & 30835 & & 11 \\
\hline
\end{tabular}

Source: - Computed by the authors.

Index of Women Self-Help Groups: - Women self-help groups are important parameter of the Women Empowerment. It is created to micro level regional development. The number of women self-help groups is closely associated with the development of human resource. For the developing country like India, the number of women self-help groups may be regarded as a potential tool to measure the development of human resource. The index has been calculated on the basis of the following formulaIndex of Women Self-Help Groups $=($ No. of Women Self-Help Groups $\div$ Total No of Self Help Groups $) \times$ 100

Table 5

Index of Women Self-Help Groups

\begin{tabular}{|l|l|l|l|l|}
\hline Name of C.D Blocks & $\begin{array}{l}\text { No of Self-help } \\
\text { Groups }\end{array}$ & $\begin{array}{l}\text { No of Women Self- } \\
\text { help Groups }\end{array}$ & $\begin{array}{l}\text { Index of Women Self- } \\
\text { Help Groups. }\end{array}$ & Ranks. \\
\hline Nalhati-I & 922 & 572 & 62.040 & 8 \\
\hline Nalhati-II & 402 & 156 & 38.806 & 19 \\
\hline Murarai-I & 750 & 488 & 65.067 & 7 \\
\hline Murarai-II & 796 & 652 & 81.910 & 1 \\
\hline Mayureswar-I & 706 & 342 & 48.442 & 15 \\
\hline Mayureswar-II & 728 & 386 & 53.022 & 14 \\
\hline Rampurhat-I & 676 & 417 & 61.686 & 9 \\
\hline Rampurhat-II & 530 & 233 & 43.962 & 16 \\
\hline Mohammad Bazar & 757 & 517 & 68.296 & 6 \\
\hline Sainthia & 758 & 521 & 68.734 & 5 \\
\hline Dubrajpur & 569 & 240 & 42.179 & 18 \\
\hline Rajnagar & 703 & 418 & 59.459 & 10 \\
\hline Suri-I & 580 & 295 & 76.379 & 3 \\
\hline Suri-II & 672 & 471 & 43.899 & 17 \\
\hline Khoyrasole & 829 & 598 & 56.815 & 12 \\
\hline Bolpur-Sriniketan & 828 & 594 & 72.222 & 4 \\
\hline Labhpur & 1034 & 576 & 80.335 & 11 \\
\hline Nanoor & 717 & 468 & 55.319 & 2 \\
\hline Illambazar & 846 & & 13 \\
\hline
\end{tabular}

Source: - Computed by the authors. 
Index of School: - Schools is one of the important parameter of human resource. The number Schools are closely associated with the development of human resource. The index has been calculated on the basis of the following formula-

Index of Schools $=($ Total Schools of the Block $\div$ Total Students of the Block $) \times 100$

Table 6

Index of Schools.

\begin{tabular}{|l|l|l|l|l|}
\hline Name of C.D Blocks & No of Schools & Total Students & Index of Schools & Ranks \\
\hline Nalhati -I & 156 & 39054 & 0.399 & 16 \\
\hline Nalhati-II & 82 & 28189 & 0.291 & 18 \\
\hline Murarai-I & 115 & 35366 & 0.325 & 17 \\
\hline Murarai-II & 104 & 37956 & 0.274 & 19 \\
\hline Mayureswar-I & 137 & 30212 & 0.453 & 14 \\
\hline Mayureswar-II & 102 & 22010 & 0.463 & 13 \\
\hline Rampurhat-I & 164 & 28912 & 0.567 & 3 \\
\hline Rampurhat-II & 136 & 32920 & 0.413 & 15 \\
\hline Mohammad Bazar & 144 & 30912 & 0.466 & 12 \\
\hline Sainthia & 200 & 31880 & 0.627 & 2 \\
\hline Dubrajpur & 158 & 29044 & 0.544 & 4 \\
\hline Rajnagar & 101 & 12732 & 0.793 & 1 \\
\hline Suri-I & 102 & 19674 & 0.518 & 8 \\
\hline Suri-II & 90 & 16709 & 0.539 & 5 \\
\hline Khoyrasole & 141 & 26498 & 0.532 & 6 \\
\hline Bolpur-Sriniketan & 174 & 36438 & 0.478 & 10 \\
\hline Labhpur & 190 & 38577 & 0.493 & 9.478 \\
\hline Nanoor & 187 & 39131 & 0.523 & 11 \\
\hline Illambazar & 156 & 29803 & & 7 \\
\hline
\end{tabular}

Source: - Computed by the authors.

HUMAN RESOURCE DEVELOPMENT INDEX OF BIRBHUM DISTRICT:-

Human Resource Development Index for 19 blocks of Birbhum District is calculated with the help of the above six indices. The formula is:

Human Resource Development Index (HRDI) = 1/6 (Index of Urbanization + Index of Workers + Index of Literacy + Index of Female Literacy + Index of Women Self-Help Groups + Index of Schools)

Table 7

Human Resource Development Index of Birbhum District

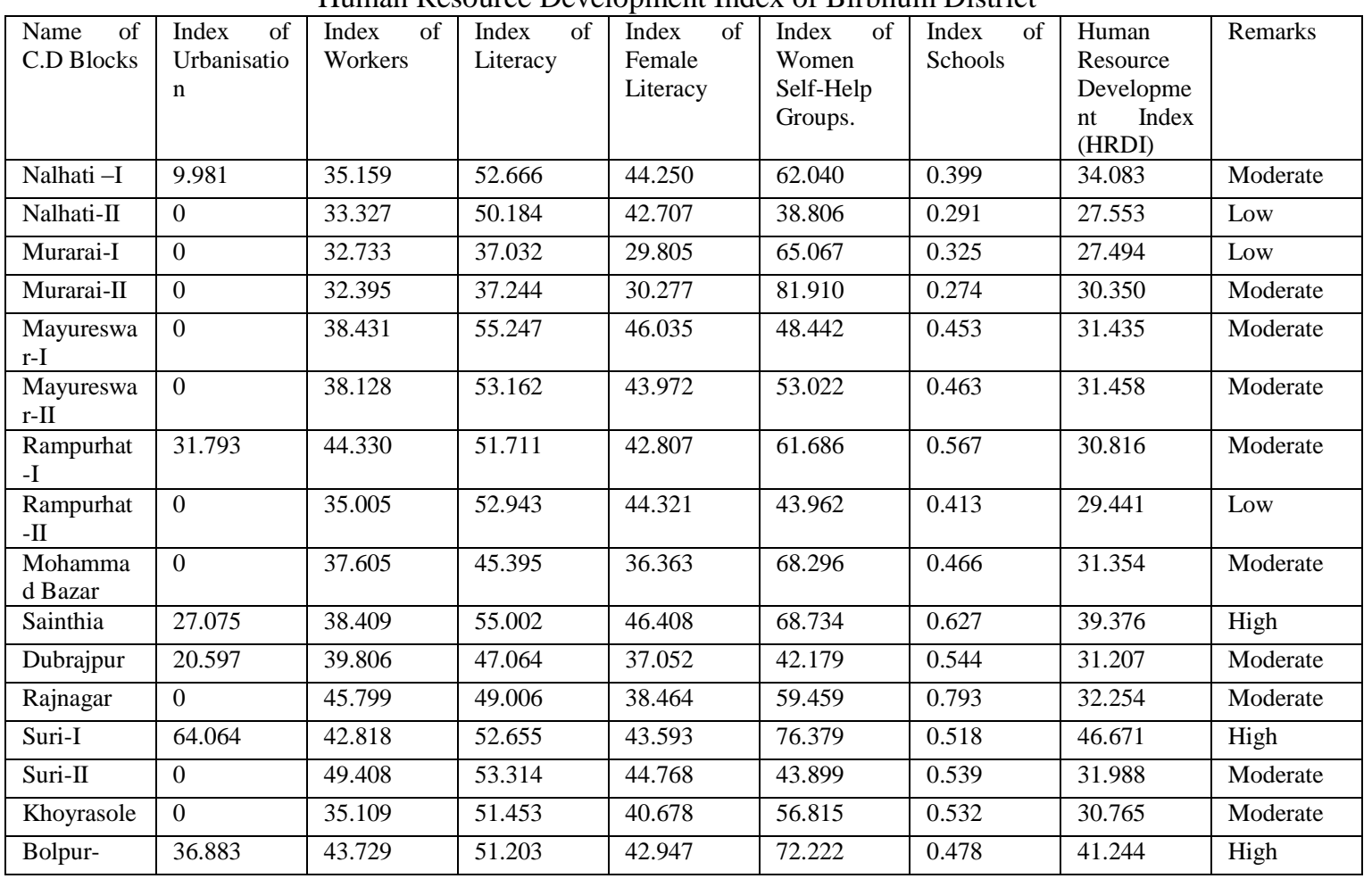


Human Resource Development Of Birbhum District - A Critical Study

\begin{tabular}{|l|l|l|l|l|l|l|l|l|}
\hline Sriniketan & & & & & & & & \\
\hline Labhpur & 0 & 35.395 & 52.590 & 44.618 & 57.447 & 0.493 & 31.757 & Moderate \\
\hline Nanoor & 0 & 36.882 & 51.885 & 44.694 & 80.335 & 0.478 & 35.712 & High \\
\hline Illambazar & 0 & 36.526 & 52.243 & 43.766 & 55.319 & 0.523 & 31.396 & Moderate \\
\hline
\end{tabular}

Source: - Computed by the authors.

The whole study area has been divided into three regions basis of Human Resource Development Index.

\section{Area of high Human Resource Development:-}

The blocks with index value above 35.00 consider as "area of high human resource development". There are four blocks in this category. These are Suri-I, Bolpur-Sriniketan, Sainthia, Nanoor. These blocks are highly developed in all the six parameters. Of all the blocks Suri-I ranks highest with the HRDI value of 46.671. The District headquarter located in Suri-I block. Apart from urbanisation, literate population, women self-help groups, educational facility, total workforce have helped Suri-I to bag highest place in Human Resource Development Index in Birbhum District. Sainthia is a highest of female literacy index.

\section{Area of Moderate Human Resource Development:-}

The blocks with index value 30.00 to 35.00 consider as "area of moderate human resource development". There are twelve blocks in this category. These are Nalhati -I, Murarai-II, Mayureswar-I, Mayureswar-II, Rampurhat-I, Mohammad Bazar, Dubrajpur, Rajnagar, Suri-II, Khoyrasole, Labhpur, Illambazar. Workers index of Suri-II block is very good. Literacy index of Mayureswar-I block is topper positions. School index of Rajnagar block is good.

\section{Area of Low Human Resource Development:-}

Blocks with index value below 30.00 consider as "area of low human resource development". There are three blocks in this category. These are Nalhati-II -I, Murarai-I Rampurhat-II. These blocks are low developed in all the six parameters. Of all the blocks Murarai-I ranks lowest. Among them Murarai-I is with the lowest value (27.494), and is the most less developed and backward block of Birbhum District.

\section{Conclusion:-}

From the above analysis it shown that Suri-I block have done well in Human Resource Development Index. It can be remarked that a large part of the district is low and moderate human resource development. This situation is very bad. Government policy is very need to increasing of human resource development.

\section{Reference:-}

[1]. District Statistical Handbook, Birbhum, 2010 - 2011: Bureau of Applied Economics and Statistics, Government of West Bengal.

[2]. Govt. of West Bengal (2001), District Census Handbook, West Bengal.

[3]. District Human Development Report, Birbhum, 2009.

[4]. Tripathi, R. S. and Tiwari, R. P.: Changing Pattern in Human Resource Development of Msdhya Pradesh. Geog. Review of India. Vol. 57, No. 4, p. 376-381

[5]. Roy Debasish "Status of Human Development in the District of Birbhum at Block Level "International Journal of Sociology and Anthropology, Vol. 1, No. 2, September 2013, pp. 104-110.

[6]. Birbhum District Gazetteers, Govt. of West Bengal. 